\title{
The pituitary-specific regulatory gene GHF1 contains a minimal cell type-specific promoter centered around its TATA box
}

\author{
Alison McCormick, ${ }^{1}$ Helen Brady, ${ }^{1}$ Jun Fukushima, and Michael Karin ${ }^{2}$ \\ Department of Pharmacology M-036, Center for Molecular Genetics, University of California, San Diego, School of \\ Medicine, La Jolla, California 92093 USA
}

\begin{abstract}
GHF-1 is a pituitary-specific transcription factor responsible for activation of the growth hormone (GH) gene. The GHF1 gene is expressed exclusively in cells of the somatotrophic lineage, and its transcription is extinguished in somatic cell hybrids. The minimal sequences required for differential transcription of GHF1 in GH-expressing and -nonexpressing cell lines and somatic cell hybrids were localized to a 15-bp region surrounding and including its TATA box. This 15-bp fragment acts as a cell type-specific promoter element and is recognized by a transcription factor present in GH-expressing cell lines. Hence, in addition to enhancers and upstream promoter elements, the TATA element (TATA box plus surrounding sequences) can be, in certain cases, an important determinant of cell-type-specific transcription.
\end{abstract}

[Key Words: GHF1; pituitary-specific regulatory gene; cell-type-specific promoter; transcription factor; TATA box]

Received January 7, 1991; revised version accepted May 24, 1991.

Exclusive expression of the growth hormone $(\mathrm{GH})$ gene in anterior pituitary somatotrophs is largely determined by binding of transcription factor GHF-1 to two sites within its promoter (Bodner and Karin 1987; for review, see Karin et al. 1990). GHF-1, also known as Pit-1, is a homeo domain protein encoded by a gene whose expression is restricted to cell types that belong to the somatotrophic lineage (Bodner et al. 1988; Ingraham et al. 1988). Expression of GHF-1 transcripts and protein is highly regulated, and the accumulation of GHF-1 protein correlates both temporally and spatially with activation of the GH gene (Dollé et al. 1990). The cell-type specificity of $G H$ transcription can be explained by the restricted distribution of its activating factor GHF-1 (Karin et al. 1990). The GHF1 gene is also controlled by a yetto-be-identified extinguisher responsible for extinction of GH expression in hybrids of pituitary and fibroblast cells (McCormick et al. 1988). Extinction is a poorly understood regulatory mechanism, revealed by studies on somatic cell hybrids (Thompson and Gelehrter 1971; Davidson 1974; Weiss and Chaplain 1971; Killary and Fournier 1984), but it may contribute to the restricted expression of cell-type-specific trans-activators seen in vivo (Baumhuerter et al. 1990; Junker et al. 1990). Full understanding of positive and negative controls that es-

\footnotetext{
${ }^{1}$ These authors made equal contributions to this work.

${ }^{2}$ Corresponding author.
}

tablish cell-type-specific patterns of gene expression requires careful analysis of the mechanisms regulating the activity and expression of the regulators themselves.

Such studies were recently initiated with GHF1, whose promoter region was identified and some of the sequences required for its cell-type-specific and regulated expression determined (McCormick et al. 1990). The GHF1 promoter contains two binding sites for the ubiquitous CREB (ćAMP response element-binding) protein, which is responsible for induction of transcription in response to cAMP (Gonzalez et al. 1989). CREB is thought to be involved in stimulating the somatotrophspecific expression of GHF1 in response to the hypothalamic hormone and growth factor, GH-releasing factor. In addition, GHF1 is positively autoregulated by GHF-1 itself (McCormick et al. 1990). Positive autoregulation, however, cannot be solely responsible for the pituitaryspecific expression of $G H F 1$, because during development GHF1 transcripts appear 48-72 hr before GHF-1 protein (Dollé et al. 1990). Indeed, inactivation of the GHF-1-binding site causes only a partial reduction in GHF1 promoter activity, without eliminating its pituitary-specific transcription (McCormick et al. 1990). Thus, another pituitary-specific factor appears to be involved in establishment of GHF1 transcription.

To delineate further the mechanisms responsible for pituitary-specific expression of GHF1 and its repression in somatic cell hybrids, we determined the minimal se- 
quences sufficient for its differential transcription in extracts of the $\mathrm{GH}$-expressing anterior pituitary cell line GH3, GH-nonexpressing Ltk $^{-}$cells, and GH3XLtk ${ }^{-}$somatic cell hybrids in which GH and GHF-1 expression are either extinguished or reactivated (McCormick et al. 1988). We found that a 15-bp region surrounding and including the TATA box of the GHF1 gene acts as a minimal pituitary-specific promoter recognized by a protein enriched in GH-expressing cells. Mutational and biochemical evidence indicate that this 15-bp sequence functions as a cell-type-specific TATA element.

\section{Results \\ Extinction of GH occurs at the level of GHF1 transcription}

Previous studies on the extinction of GH expression in somatic cell hybrids correlated extinction with disappearance of GHF-1 protein and RNA (McCormick et al. 1988). To determine the level at which GHF-1 expression is regulated in this system, we examined the presence of GHF1 transcripts in nuclear RNA extracted from the parental cell lines $\mathrm{GH} 3$ (GH positive) and $\mathrm{Ltk}^{-}$(GH negative), and their hybrids $\mathrm{C} 2$ (GH positive), $\mathrm{C} 6 / \mathrm{GH}$ negative), and $\mathrm{C} 19$ (GH negative). Processed and unprocessed GHF1 transcripts were present only in the $\mathrm{GH}$ positive cell lines GH3 and C2 (data not shown). Southern blotting analysis revealed the presence of the rat GHF1 gene in all of the hybrids (data not shown). To determine whether extinction is mediated at the level of GHF1 transcription, whole-cell extracts (WCE) of the various cell lines were used for testing the efficiency of the $G H F 1$ promoter by in vitro transcription reactions analyzed by primer extension (Bodner and Karin 1987; McCormick et al. 1988|. A 115-nucleotide cDNA product corresponding to transcripts initiated at the GHF1 promoter (McCormick et al. 1990) was detected only in reactions that contained either $\mathrm{GH} 3$ or $\mathrm{C} 2$ extracts (Fig. 1). No such transcripts were generated upon incubation of GHF1-chloramphenicol acetyltransferase (CAT) with either Ltk $^{-}$or C6 extracts. Mixing experiments indicated that the GHF1 promoter was active regardless of the order of extract addition. Therefore, lack of GHF1 transcription in $\mathrm{Ltk}^{-}$cell extracts and probably in the C6 and C19 somatic cell hybrids is unlikely to be caused by dominant repressors that bind tightly to the promoter.

These conclusions were supported by DNase I footprinting experiments (Fig. 2). A large area of protection (footprint I), determined previously to encompass sequences from -78 to -23 of the GHF1 promoter (McCormick et al. 1990), is seen upon incubation of the GHF1 probe with the GH3 or C2 extracts. This footprint is not observed upon incubation with the $\mathrm{Ltk}^{-}, \mathrm{C} 6$, and C19 extracts. On the other hand, these extracts contain factors that generate footprints 1 and 2 covering sequences from -50 to -40 and -80 to -63 , respectively. Other areas of protection can be detected upstream to footprint 2 . However, because they lie up-

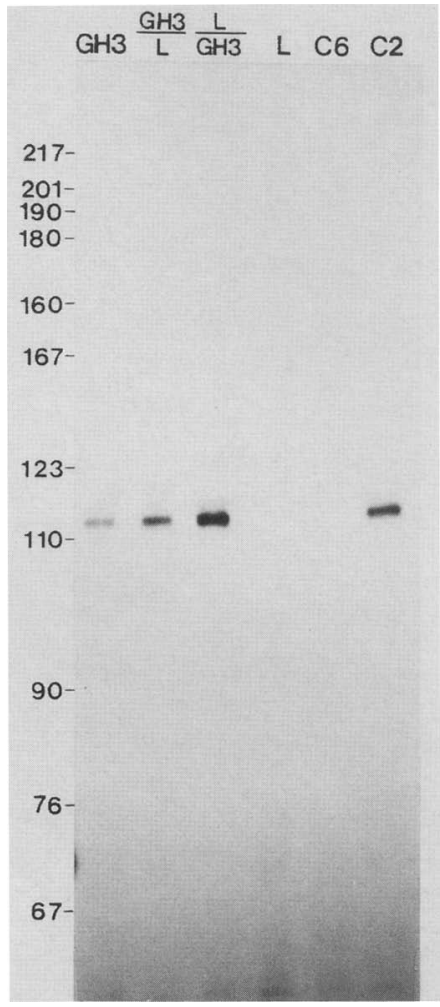

Figure 1. Analysis of GHF1 promoter activity in parental and hybrid cells. A GHF1-CAT ( $\left.\Delta 5^{\prime}-2000\right)$ plasmid (100 ng) was incubated with WCE $(75 \mu \mathrm{g})$ prepared from the indicated cell lines, under standard in vitro transcription reaction conditions (McCormick et al. 1988). After a 60-min reaction, the generated transcripts were quantitated by primer extension. In the mixing experiments, the GHF1-CAT template was first incubated with $75 \mu \mathrm{g}$ of one extract for $30 \mathrm{~min}$ on ice in the absence of ribonucleotide triphosphates (rNTPs), followed by an equal amount of the second extract, addition of rNTPs, and incubation at $30^{\circ} \mathrm{C}$ for $60 \mathrm{~min}$. The primer extension products were separated on a $10 \%$ sequencing gel and visualized by autoradiography for $12 \mathrm{hr}$.

stream of position -90 , the previously described $5^{\prime}$ border of the region involved in cell-type-specific expression (McCormick et al. 1990), they were not investigated in further detail. Thus, footprint I correlates with GHF1 transcription, whereas its absence and the presence of footprints 1 and 2 correlate with lack of promoter activity.

\section{Definition of the minimal GHF1 promoter}

To determine the sequence requirements for differential GHF1 transcription, progressive $5^{\prime}$ deletion mutants were constructed and tested for activity in WCE of expressing (GH3, C2) and nonexpressing ( $\left.\mathrm{Ltk}^{-}, \mathrm{C} 6\right)$ cells. To control for the activity of the different extracts and efficiency of the reactions, the human $\alpha$-globin gene was included as an internal control. Transcripts initiated from the $\alpha$-globin promoter generate a 66 -nucleotide primer extension product. 


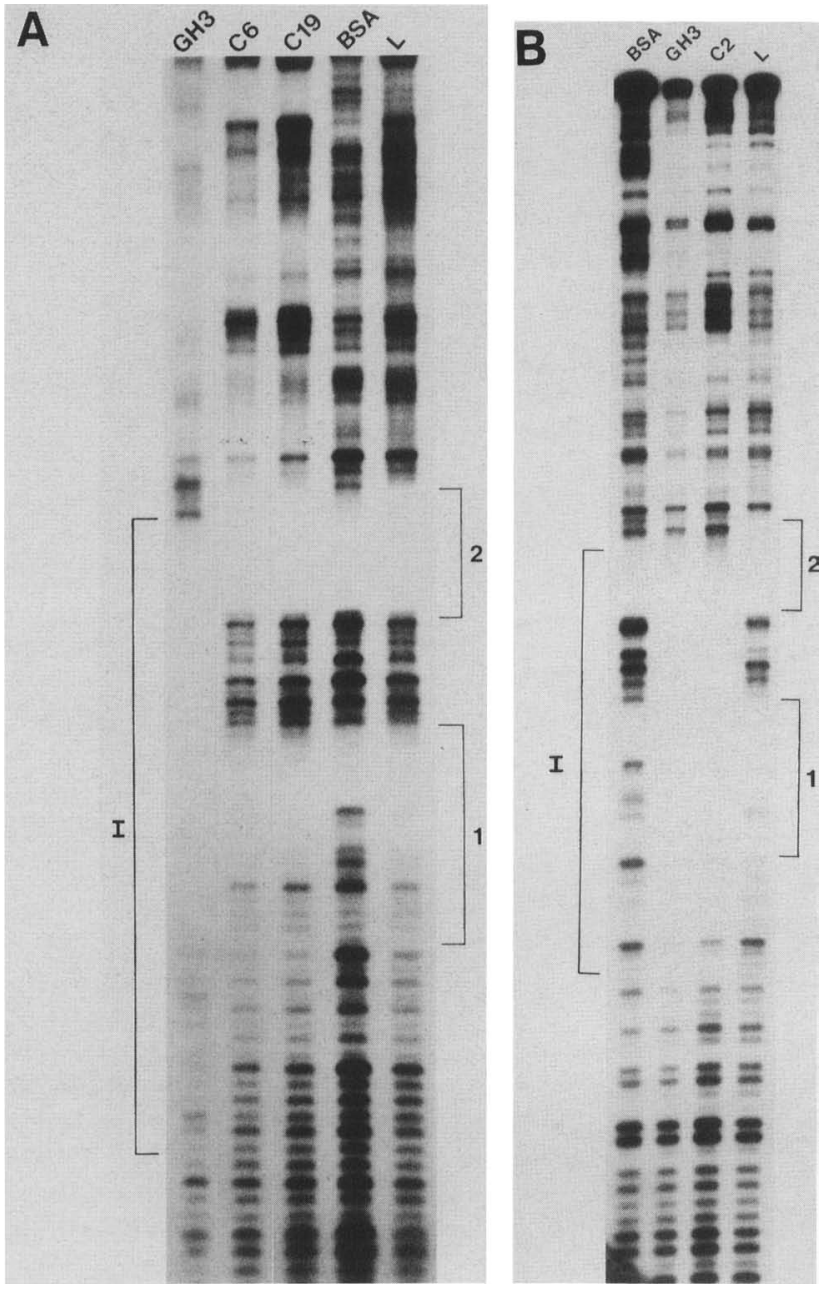

Figure 2. Footprint analysis. GHF1 probe, end-labeled at position +1 , was incubated with $30 \mu \mathrm{g}$ of the indicated WCEs, which were partially enriched by heparin-agarose chromatography (Bodner and Karin 1987) or with $30 \mu \mathrm{g}$ of BSA. The location of protein-binding sites was determined by DNase I footprinting and is marked by brackets. $(I)-78$ to -23 ; $(1)-50$ to $-40 ;(2)-80$ to -63 . $(A, B)$ Two different experiments with the same probe.

All of the GHF1 promoter mutants thus examined exhibited differential transcription (Fig. 3). A small increase in transcription in $\mathrm{GH} 3$ and $\mathrm{C} 2$ extracts was seen upon deletion of sequences between -2000 and -200 , whereas deletion of sequences between -2000 and -90 had no further effect. Deletion of sequences between -90 and -51 led to a two- to threefold decrease in transcription in expressing extracts. This decrease correlates with deletion of a GHF-1-binding site involved in positive autoregulation (McCormick et al. 1990). A further deletion to -41 had no effect on transcription in extracts of expressing cell lines but appeared to result in a slight increase in basal promoter activity in nonexpressing extracts. Hence, sequences located between positions -41 and +1 are sufficient for differential transcription in vitro. Therefore, the factors that bind to sites 1 and 2, which are located upstream of -41 , are unlikely to be responsible for the transcriptional inefficiency of the GHF1 promoter in nonexpressing cell extracts. On the other hand, a pituitary-specific factor binding to the $3^{\prime}$ half of footprint I could be responsible for the increased activity of the truncated GHF1 promoter in the GH3 and $\mathrm{C} 2$ extracts. The $5^{\prime}$ half of footprint I was shown to contain a GHF-1-binding site (McCormick et al. 1990).

\section{A 15-bp minimal promoter}

Next we tested whether a synthetic oligodeoxynucleotide containing GHF1 sequences from -39 to -24 can function as a cell-type-specific promoter in vitro. The $3^{\prime}$ border of this fragment was chosen according to the $3^{\prime}$ border of the pituitary-specific footprint (I in Fig. 2). This synthetic DNA fragment was inserted upstream of position -46 of a truncated $T K$ promoter (Fig. 4A). The resultant hybrid promoter directed efficient transcription in GH3 extracts but not in $\mathrm{Ltk}^{-}$extracts (Fig. 4B). The transcripts were initiated $29 \mathrm{bp}$ downstream of the first (5'-most) T of the GHF1 TATA element, and no specific initiation was observed from the $T K$ promoter itself. [The primer extension products migrating at the size expected for the $T K$-initiated transcripts (82 nucleotides) are nonspecific products from the $\alpha$-globin gene. No such products were seen in the absence of the $\alpha$-globin template]. The truncated $T K$ promoter itself appeared inactive in both extract types. The ability of the 15-bp GHF1 TATA region oligonucleotide to direct initiation of transcription to a site located $25-30 \mathrm{bp}$ downstream is in agreement with the known property of TATA elements (Breathnach and Chambon 1981). However, unlike other TATA elements, the GHF1-derived element functions in a cell-type-specific manner. The efficiency of the 15-bp fragment is similar to that of the $\triangle 5^{\prime}-41$ GHF1 promoter.

To exclude the possibility that part of the GHF1 TATA element activity is due to the action of GHF-1 itself, we used an oligodeoxynucleotide representing the high-affinity GHF-1-binding site of the $G H$ promoter (Bodner and Karin 1987) to compete for GHF-1 binding. Although a $10^{3}$-fold molar excess of the GHF-1-binding site led to a significant decrease in transcription from the $G H$ promoter, it had only a very small effect on the weaker GFTATA/TK hybrid promoter (Fig. 4C). These results are in agreement with previous findings, which indicate that GHF-1 does not bind to this part of the GHF1 promoter (McCormick et al. 1990).

\section{Mutational analysis of the GHF1 TATA element}

These results suggested that the TATA box of GHF1, in combination with its flanking sequences, functions as a cell-type-specific minimal promoter. To investigate this possibility further, the GHF1 TATA box region (from -39 to -24 ) was replaced with the corresponding regions of the herpes simplex virus (HSV)-TK and human $\alpha$-globin promoters to generate the GT and GG mutant promoters (Fig. 5A). We also substituted the corresponding region of the HSV-TK promoter with the GHF1 


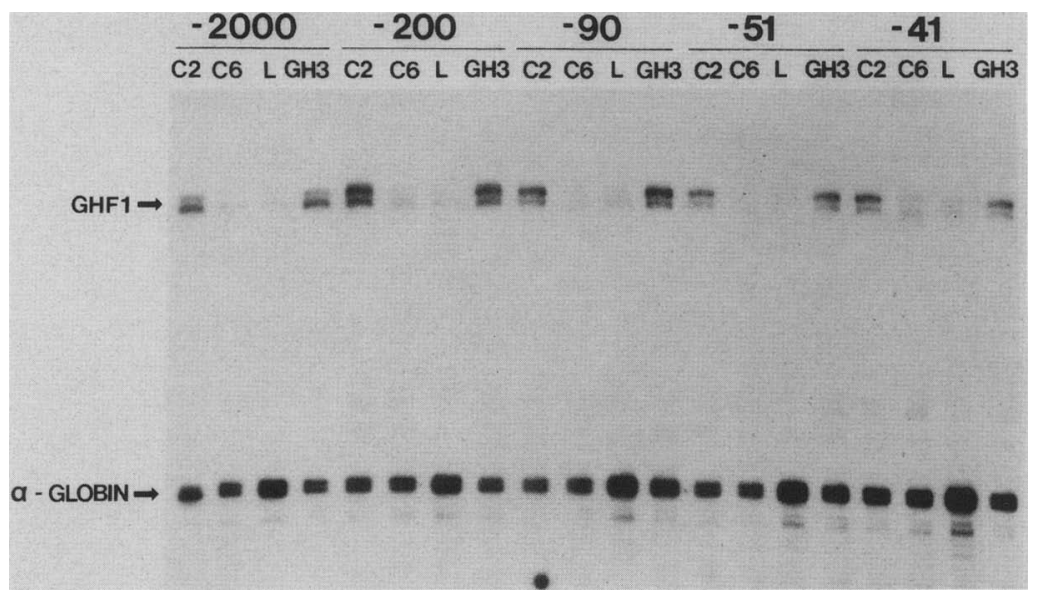

Figure 3. Analysis of $5^{\prime}$-deletion mutants. The transcriptional efficiency of progressive $5^{\prime}$ deletions of the GHF1-CAT fusion gene was determined by in vitro transcription in $\mathrm{GH} 3, \mathrm{Ltk}^{-}, \mathrm{C} 6$, and $\mathrm{C} 2$ extracts. The end point of each deletion mutant is indicated in the upper panel. Transcription reactions contained $100 \mathrm{ng}$ of each of the GHF1-CAT constructs, $200 \mathrm{ng}$ of p $\alpha$-globin, serving as an internal control, and $75 \mu \mathrm{g}$ of protein extract.

TATA region, to generate the TG mutant promoter. Activities of all promoters were tested in GH3 and Ltkextracts. Although the efficiency of the TG promoter is lower than that of the wild-type GHF1 promoter, the results shown in Figure $5 \mathrm{~B}$ indicate that both of these promoters, which contain the GHF1 TATA region, were preferentially transcribed in the GH3 extract. The differential efficiency of the GHF1 and TG promoters is probably due to the different strengths of their upstream elements. Because the upstream elements of the GHF1 promoter are inactive in $\mathrm{Ltk}^{-}$cells, it is difficult to derive any conclusions from the lack of activity of the GT and GG promoters in this extract. However, the results obtained with the GH3 extract demonstrate that substitution of the TATA element of the weak TK promoter with the TATA element of the GHF1 promoter converts the $T K$ promoter to a pituitary-specific promoter in the absence of pituitary-specific upstream elements. Furthermore, substitution of the GHF1 TATA element with the corresponding elements of the $T K$ or $\alpha$-globin genes abolished its GH3-specific activity despite the presence of pituitary-specific upstream elements.

To delineate further the sequence requirements for the pituitary-specific TATA function, single and clustered point mutations were introduced into the GHF1 TATA box and its immediate surroundings (Fig. 6A). These changes were introduced into the $\Delta 5^{\prime}-200$ GHF1 promoter so that binding sites for the upstream activators GHF-1 and CREB (McCormick et al. 1990) were retained. Replacement of the first $\mathrm{T}$ of the TATAA sequence with a G (T1) had the most severe effect on transcription in GH3 extracts (11-fold reduction). Replacement of the G preceding the TATAA sequence with a $\mathrm{T}(\mathrm{T} 2)$ also led to decreased promoter activity in the GH3 extract, although the effect was not as large as that of the T1 mutation. Another point mutation (T3) replacing an $A$ downstream of the TATAA sequence with a $\mathrm{C}$ also decreased activity, but the effect was less than twofold (Table 1). Two clustered point mutations affecting sequences either downstream (T4) or upstream (T5) of the TATA box also decreased transcriptional efficiency, although the downstream mutations were more influen- tial. With the exception of Tl, none of these mutations had a significant effect on the low basal transcription of GHF1 in the HeLa cell extracts; and even for T1 the effect on promoter activity in this heterologous extract (twofold reduction) was significantly smaller than its effect on GHF1 promoter activity in GH3 extracts (Table 1). Longer exposure of the autoradiogram shown in Figure $6 \mathrm{~B}$ revealed similar effects on the even lower basal transcription in the $\mathrm{Ltk}^{-}$extract.

These results indicate that sequences immediately flanking the GHF1 TATA box are mostly important for promoter function in GH3 extracts but are not very critical for low basal activity in heterologous extracts. We also examined whether these sequences are important for GHF1 promoter activity in vivo. Wild-type and $\mathrm{mu}$ tant GHF1-CAT constructs were transfected into GH3 cells incubated in the absence or presence of forskolin, an activator of adenylate cyclase. Previous work indicated that GHF1 is a CAMP-inducible gene, and the use of forskolin increased the signal-to-noise ratio of such transfection experiments (McCormick et al. 1990). As documented in Table 2, all of the mutations were found to decrease $G H F 1$ promoter activity in vivo. Thus, the GHF1 TATA region plays an important role both in vitro and in vivo. Unfortunately, because of the very low activity obtained upon transfection of GHF1-CAT into other cell types (McCormick et al. 1990) it was impossible to evaluate the effects of these mutations on GHF1 promoter activity in $\mathrm{Ltk}^{-}$or HeLa cells.

\section{Different requirements for GHF1 and $\alpha$-globin transcription}

Although the minimal GHF1 promoter described above is centered around the TATA box, it acts in a cell-typespecific manner and is therefore expected to interact with a unique factor that does not recognize a promoter, such as $\alpha$-globin, which does not display the same specificity. The experiments shown in Figure 7 support this notion. Preincubation of a GH3 extract with a 50 -fold molar excess of a 15-bp GHF1 TATA element oligonucleotide decreased the transcriptional activity of the 


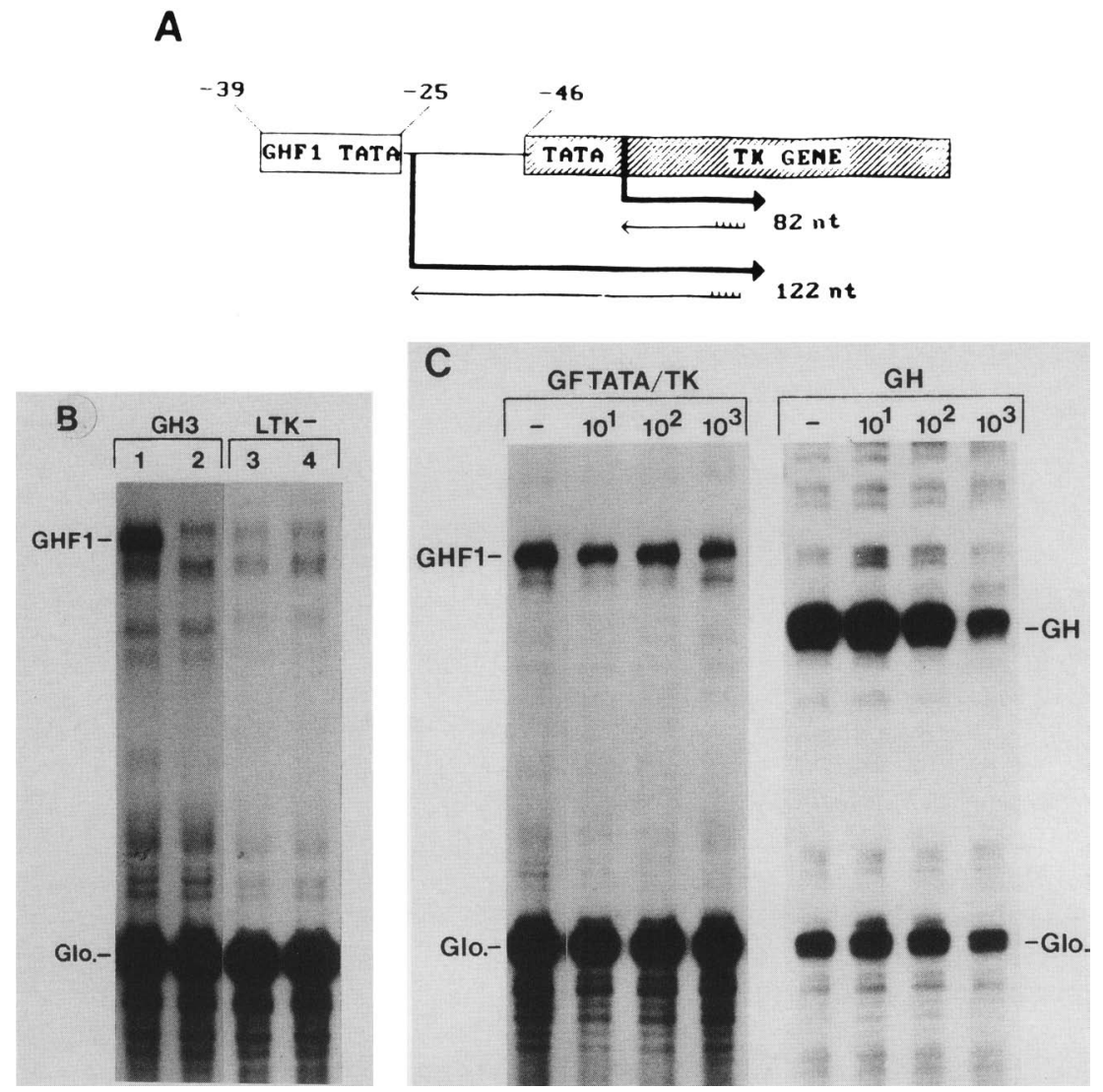

Figure 4. Construction and analysis of the minimal GHF1 promoter. $(A)$ Construction of the minimal GHF1 promoter. A synthetic double-stranded oligodeoxynucleotide corresponding to GHF1 sequences from -39 to -24 (see Fig. $5 \mathrm{~A}$ ) was inserted upstream to the truncated HSV-TK $\left(\Delta 5^{\prime}-46\right)$ promoter. The length of primer extension products that correspond to transcripts initiated $30 \mathrm{bp}$ downstream of the GHF1 TATA element and from the authentic TK promoter is indicated. $(B)$ In vitro transcription of GFTATA/TK (lanes 1 and 3 ) and $T K \Delta 5^{\prime}-46$ (lanes 2 and 4 ) in GH3 and Ltk extracts. Reactions contained $100 \mathrm{ng}$ of the various test templates and $200 \mathrm{ng}$ of the $\alpha$-globin internal control template. (C) GHF1 minimal promoter activity is not conferred by GHF-1. GH3 extracts were incubated with up to $10^{3}$-fold molar excess (oligodeoxynucleotide : template) of a double-stranded oligodeoxynucleotide representing the high-affinity GHF-1 site of the GH gene for $15 \mathrm{~min}$ on ice. GFTATA/TK and GH-CAT templates (100 ng each) were added together with the $\alpha$-globin control template ( $200 \mathrm{ng}$ ), and in vitro transcription reactions were performed and analyzed by primer extension. The location of extension products corresponding to transcripts initiated at the minimal GHF1 promoter and the $G H$ and $\alpha$-globin promoters is indicated.

GHF1 promoter in comparison to its activity either in the absence of any competitor or in the presence of 50 fold molar excess of a 15-bp oligonucleotide spanning the $\alpha$-globin TATA region (Fig. 7A). On the other hand, the GHF1 TATA element oligonucleotide did not cause a meaningful decrease in $\alpha$-globin promoter activity in comparison to the activity observed in the absence of any competing oligonucleotide. The $\alpha$-globin TATA element oligonucleotide led to a nonspecific increase in the activity of both promoters, probably by titrating a general inhibitor of transcription present in these extracts. These results suggest that the GHF1 TATA element interacts with a factor that is not involved in transcription of the $\alpha$-globin promoter.

To compare the transcriptional requirements of the GHF1 and $\alpha$-globin promoters further, we examined their sensitivity to mild heat treatment, which is thought to inactivate the TATA recognition factor TFIID (Nakajima et al. 1988). Treatment of the GH3 extract at $47^{\circ} \mathrm{C}$ decreased transcription of the $\alpha$-globin and $G H$ promoters while having no effect on the truncated GHF1 promoter (Fig. 7B). Similar results were found with the adenovirus major late promoter as an internal control (data not shown). These and other results (see Fig. 10, below) suggest that transcription of the GHF1 promoter in GH3 extracts does not depend on the heat-sensitive form of the TFIID complex. On the other hand, the low basal transcription of GHF1 in Ltk ${ }^{-}$extracts appears to be TFIID-dependent as it is heat sensitive /data not shown). Inhibition of GHF1 transcription by $1 \mu \mathrm{g} / \mathrm{ml}$ of $\alpha$-amanitin (Fig. 7A) indicates that it is nonetheless transcribed by RNA polymerase II.

\section{The GHF1 TATA element interacts with} a cell-type-specific factor

Further evidence for a pituitary-specific factor interacting with the minimal GHF1 promoter was provided by 
A

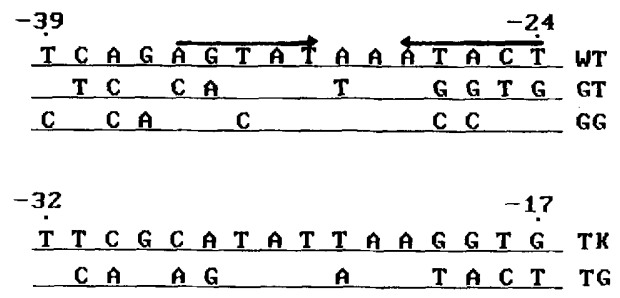

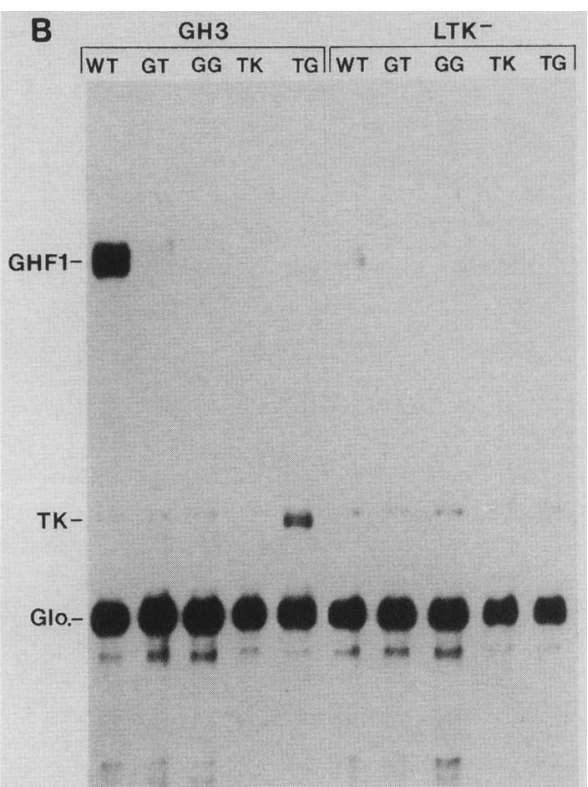

Figure 5. The GHF1 TATA element is responsible for pituitary-specific transcription. (A) The sequence of the GHF1 TATA box region is indicated (WT), as well as the nucleotide changes used to convert it to the corresponding sequences of the TK (GT) and $\alpha$-globin (GG) promoters. Also indicated is the sequence of the TATA box region of the HSV-TK gene (TK) and the nucleotide substitutions used to convert it to the GHF1 TATA sequence (TG). The arrows indicate a palindromic sequence. (B) Transcriptional analysis of the GHF1-WT $\left(\Delta 5^{\prime}-200\right)$, GT $\left(\Delta 5^{\prime}-200\right), \mathrm{GG}\left(\Delta 5^{\prime}-200\right), T K\left(\Delta 5^{\prime}-109\right)$ and TG( $\left.\Delta 5^{\prime}-109\right)$ promoters in GH3 and Ltk ${ }^{-}$extracts. Primer extension products corresponding to transcripts initiated at the GHF1,TK and $\alpha$-globin (internal control) promoters are indicated.

cross-linking experiments. Incubation of a labeled GHF1 TATA element oligonucleotide with GH3 extracts and irradiation with UV generated several protein-DNA adducts, the most abundant of which migrated on SDSpolyacrylamide gels with apparent molecular masses of
40 and $45 \mathrm{kD}$ (Fig. 8). The $45-\mathrm{kD}$ complex may represent the cross-linking of two DNA strands to the same polypeptide, whereas the $40-\mathrm{kD}$ complex could be attributed to cross-linking of a single DNA strand. The lower abundance complexes migrating at $\sim 80$ and $90 \mathrm{kD}$ may rep-
A

TCAGAGTATAAATACT WT

\begin{tabular}{rrr}
$G G$ & T1 \\
\hline$T$ & T2 \\
\hline C & T3 \\
\hline GCA C & T4 \\
\hline & T5
\end{tabular}

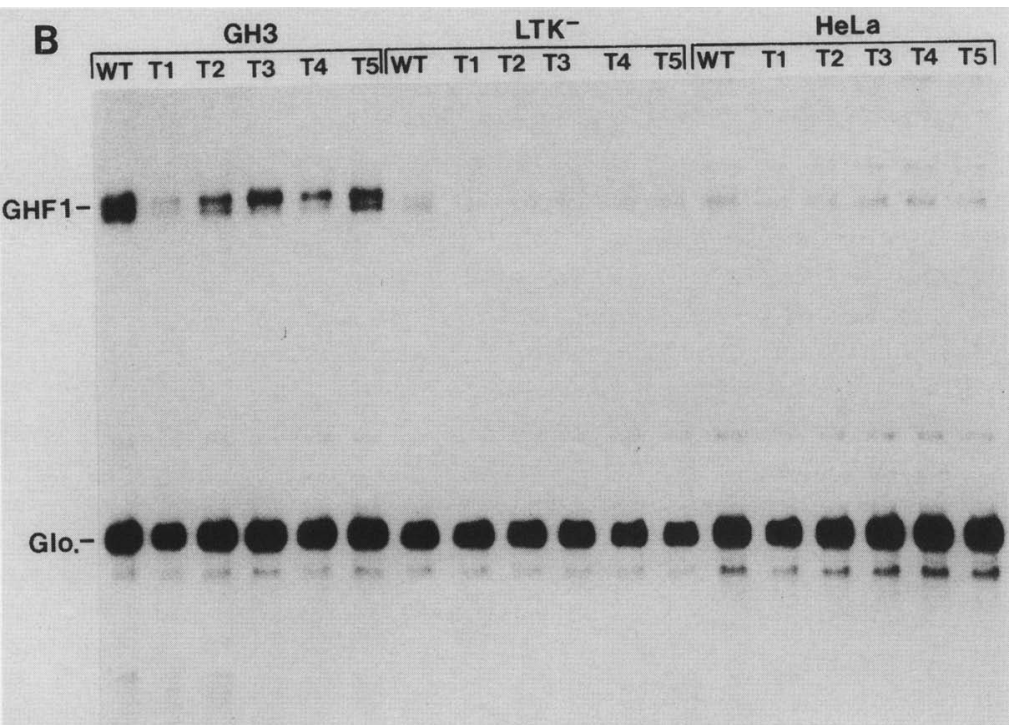

Figure 6. Mutational analysis of the GHF1 TATA element. (A) The sequence of the wild-type GHF1 TATA element (-39 to -24) is indicated (WT), as well as the sequences altered by the various point mutations (T1-T5). (B) Transcriptional analysis of the wild-type and mutant (T1-T5) GHF1 ( $\left.\Delta 5^{\prime}-200\right)$ promoters in GH3 and Ltk ${ }^{-}$extracts. Reactions included $100 \mathrm{ng}$ of each test template; autoradiography was for $12 \mathrm{hr}$. 
Table 1. Activity of GHF1 TATA element mutants in GH3 and HeLa cells

\begin{tabular}{lcc}
\hline Construct & GH3 & HeLa \\
\hline WT & 1.00 & 1.00 \\
T1 & 0.09 & 0.52 \\
T2 & 0.50 & 0.78 \\
T3 & 0.70 & 1.00 \\
T4 & 0.40 & 1.13 \\
T5 & 0.70 & 1.25 \\
\hline
\end{tabular}

The activities of the various GHF1 TATA element mutants are shown relative to that of the wild-type (WT) promoter. These values were derived by Cerenkov counting of the GH3 lanes in Fig. 6B and densitometric analysis of the HeLa lanes. All values were normalized to the internal control provided by the $\alpha$-globin promoter. Please note that in both extract types the wild-type GHF1 promoter was given an arbitrary value of 1.00 even though the GHF1 promoter was 11 -fold more active in the GH3 extract.

resent dimeric forms of the 40- and 45-kD complexes. In support of this notion, we found that the yield of these complexes was reduced upon shorter cross-linking times (cf. Fig. 8A with B and C). These complexes were specific, as they were competed by the wild-type GHF1 TATA region oligonucleotide but not by the Tl mutant oligonucleotide (Fig. 8A), a high-affinity GHF-1 binding site (Fig. 8B), or an $\alpha$-globin TATA element oligonucleotide (Fig. $8 \mathrm{C}$ ). In addition, the mutant $\mathrm{T} 1$ oligonucleotide bound to this polypeptide with much lower efficiency than the wild-type oligonucleotide (Fig. 8A). As expected, incubation of the GHF-1-binding site oligonucleotide with GH3 extracts led to formation of two specific complexes (Fig. 8B) with molecular masses consistent with those of GHF-1 polypeptides complexed with DNA (Castrillo et al. 1989).

Incubation of the GHF1 TATA element oligonucleotide with $\mathrm{Ltk}^{-}$extracts led to formation of a major complex with a different mobility from those formed by the GH3 extract (Fig. 8B). These complexes were not specific as they were not competed by an excess of unlabeled oligonucleotide (data not shown). Complexes of identical mobilities were also formed by incubation of the GHF-1-binding site oligonucleotide with the Ltk $^{-}$ extract, providing further evidence for their lack of specificity (Fig. 8B). A very low level of the $45-\mathrm{kD}$ proteinGHF1 TATA element adduct was formed by the C6 extract, whereas the $\mathrm{C} 2$ extract was similar in its activity to the GH3 extract (data not shown). Hence, the GHF1 TATA element interacts with a specific binding protein that is present in considerably higher levels in GH3 and $\mathrm{C} 2$ cells in comparison to $\mathrm{Ltk}^{-}$and $\mathrm{C} 6$ cells and is different from GHF-1. We named this complex, proteinpituitary transcription factor (PTF).

The pituitary-specific factor stimulates transcription of the GHF1 promoter

For further characterization PTF was partially purified from GC cell extracts (GC is a GH-expressing cell line similar to GH3). Because the footprint pattern of the GHF1 promoter is rather complex (see Fig. 2) we used the UV cross-linking assay to identify PTF activity. After initial fractionation by $\left(\mathrm{NH}_{4}\right)_{2} \mathrm{SO}_{4}$ precipitation, a GC whole-cell extract was applied to a heparin-agarose column and eluted by a stepwise $\mathrm{KCl}$ gradient. PTF activity eluted at $0.4 \mathrm{M} \mathrm{KCl}$; these fractions were pooled and applied to a Sephadex S-300 gel filtration column. As shown in Figure 9A, PTF-binding activity detected by UV cross-linking eluted from this column with an apparent molecular mass of $40 \mathrm{kD}$ (on the basis of the profiles of globular protein size markers). The same fractions also contained an activity that protected sequences between positions -39 and -22 of the GHF1 promoter from DNase I digestion (Fig. 9B). Appearance of this footprint was associated with protection of a second region located immediately upstream of the GHF1 TATA element, within plasmid sequences. A strong hypersensitive site was located between the two footprints. Most importantly, the same partially purified fractions were capable of stimulating GHF1 minimal promoter activity when added to an Ltk ${ }^{-}$extract (Fig. 9C). The transcriptional stimulatory activity coincided with the GHF1 TATA element-binding activity.

The S-300 fractions that contained PTF transcriptional activity were concentrated by application to a CM-Sepharose column eluted with a $0.1-1.0 \mathrm{M} \mathrm{KCl}$ gradient. PTFcontaining fractions were identified by the in vitro transcription assay. To compare the effect of PTF on the GHF1 and $\alpha$-globin promoters we added this partially purified preparation to normal and heat-treated GC nuclear extracts. Previous experiments indicated that GC nuclear extracts are partially deficient in PTF activity in comparison to $\mathrm{GH} 3$ whole-cell extracts and therefore serve as suitable recipients for testing PTF activity $(\mathrm{H}$.

Table 2. Activity of GHF1 TATA element mutants in vitro and in vivo

\begin{tabular}{lcc}
\hline Construct & In vitro & In vivo \\
\hline WT & 1.00 & 1.00 \\
T1 & 0.09 & 0.07 \\
T2 & 0.50 & 0.19 \\
T3 & 0.70 & 0.30 \\
T4 & 0.40 & 0.30 \\
T5 & 0.70 & 0.28 \\
GG & 0.03 & 0.20 \\
GT & 0.08 & 0.35 \\
\hline
\end{tabular}

The relative activities of the wild-type (WT) GHF1 promoter and the various mutants were determined in vitro as described in Table 1 and in vivo by transfection into GH3 cells (McCormick et al. 1990). GH3 cells were transfected with $10 \mu \mathrm{g}$ of the various $\Delta 5^{\prime}-200$ GHF1-CAT constructs (wild-type and TATA element mutants), together with $2.5 \mu \mathrm{g}$ of RSV-luciferase. Forty hours later, forskolin was added to $10 \mu \mathrm{M}$, and cells were harvested after $5 \mathrm{hr}$ of incubation. The amounts of extract used to determine CAT activity were normalized according to luciferase activity. The numbers correspond to the relative levels of CAT activity as determined by AMBIS counting of thin-layer plates. 

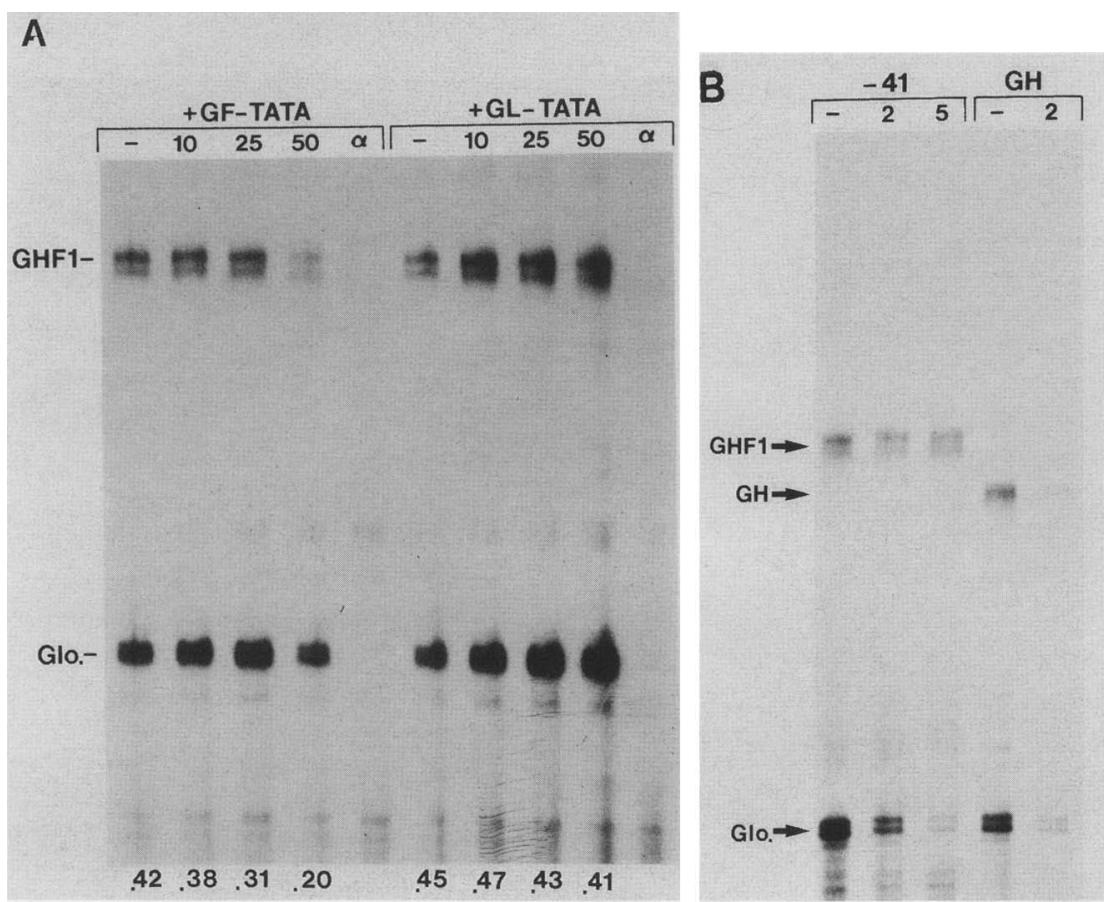

Figure 7. (A) Inhibition of GHF1 transcription by excess TATA element. GH3 extracts were incubated with 0 - to 50 -fold molar excess (oligodeoxynucleotide : template) of oligodeoxynucleotides corresponding to the GHF1 (GF-TATA) or $\alpha$-globin (GL-TATA) TATA box regions (for sequences, see Fig. 5A). After $15 \mathrm{~min}$ incubation on ice the GHF1-CAT and $\alpha$-globin templates were added and transcription reactions were carried out as described above. The reactions displayed in lanes $\alpha$ included $1 \mu \mathrm{g} / \mathrm{ml}$ of $\alpha$-amanitin in addition to 50-fold molar excess of the competing oligodeoxynucleotides. Reactions included $100 \mathrm{ng}$ of each template. The ratio of GHF1 to $\alpha$-globin transcription is indicated at the bottom of each lane. $(B)$ GHF1 transcription is insensitive to mild heat treatment. The $\Delta 5^{\prime}-41$ GHF1-CAT, GH-CAT, and $\alpha$-globin templates ( $100 \mathrm{ng}$ of each) were transcribed in either untreated GH3 nuclear extracts or in extracts that were preincubated at $47^{\circ} \mathrm{C}$ for 2 or $5 \mathrm{~min}$.
Brady, unpubl.). PTF stimulated GHF1 transcription in both extract types (Fig. 10). As shown above (Fig. 7B), preincubation of the GC extract at $47^{\circ} \mathrm{C}$ for $10 \mathrm{~min}$ did not decrease transcription from the GHF1 promoter while it severely reduced $\alpha$-globin transcription. PTF had no effect on $\alpha$-globin transcription either in the nontreated or the heat-treated GC extract.

\section{Discussion}

This work was undertaken to define the minimal sequence requirements for differential transcription of the GHF1 gene between GH-expressing and nonexpressing cell lines. To our surprise, a cis element composed of no more than $15 \mathrm{bp}$ of DNA centered around the TATA box of the GHF1 gene is sufficient for dictating its cell-typespecific transcription in vitro. As will be discussed below, this element functions as a cell-type-specific TATA element. Such findings are interesting in light of previous work indicating that TATA elements are recognized by TFIID, a protein that is thought to be present in all cell types and is functionally conserved between mammals and yeast (Buratowski et al. 1988, 1989; Cavallini et al. 1988; Nakajima et al. 1988; Hahn et al. 1989; Schmidt et al. 1989; Hoffmann et al. 1990; for review, see Lewin 1990). Therefore, a TATA element is expected to display similar activity in all cell types.

\section{A cell-type-specific TATA element?}

Cis elements that affect the efficiency of transcription initiation by RNA polymerase II are usually classified as enhancers, upstream promoter elements, and initiator elements (Breathnach and Chambon 1981; Serfling et al. 1985; Struhl 1989|. Although used most commonly, the
TATA element is only one of several types of initiator elements (Smale and Baltimore 1989; Nakatani et al. 1990). The TATA element is characterized by its ATrich sequence, whose minimal consensus is ATA, and its ability to direct the initiation of transcription from a site located 25-30 bp downstream (Breathnach and Chambon 1981). Although there are ample examples of cell-typespecific enhancers and upstream promoter elements (for review, see Maniatis et al. 1987; Renkawitz 1989), the minimal promoter of the GHF1 gene appears to be the first example of a cell-type-specific TATA element. To prevent confusion, we wish to make a functional distinction in this discussion between the TATA element and the TATA box. Although the sequence of the GHF1 TATA box is not considerably different from other TATA boxes of genes that are not pituitary-specific, the sequences that flank it appear to be unique. Analysis of other mammalian genes failed to identify a TATA box whose flanking sequences were similar to those present in GHF1 (A. McCormick, unpubl.). Hence, the cell-type specificity of the minimal GHF1 promoter is most likely dependent on flanking sequences but not on the TATA box itself. Indeed, mutations of these sequences have an adverse effect on GHF1 promoter activity in GH3 but not in Ltk ${ }^{-}$or HeLa extracts. On the basis of these findings we refer to the region encompassing the minimal GHF1 promoter that includes the TATA box and its flanking sequences as the TATA element. It may be of interest to note that the GHF1 TATA element contains an extensive palindrome (Fig. 5A). The significance of this palindrome remains to be determined.

Several criteria indicate that this part of the GHF1 promoter functions as a bona fide TATA element and not as a conventional upstream promoter element. First, its sequence is AT rich and conforms to the TATA box 
McCormick et al.
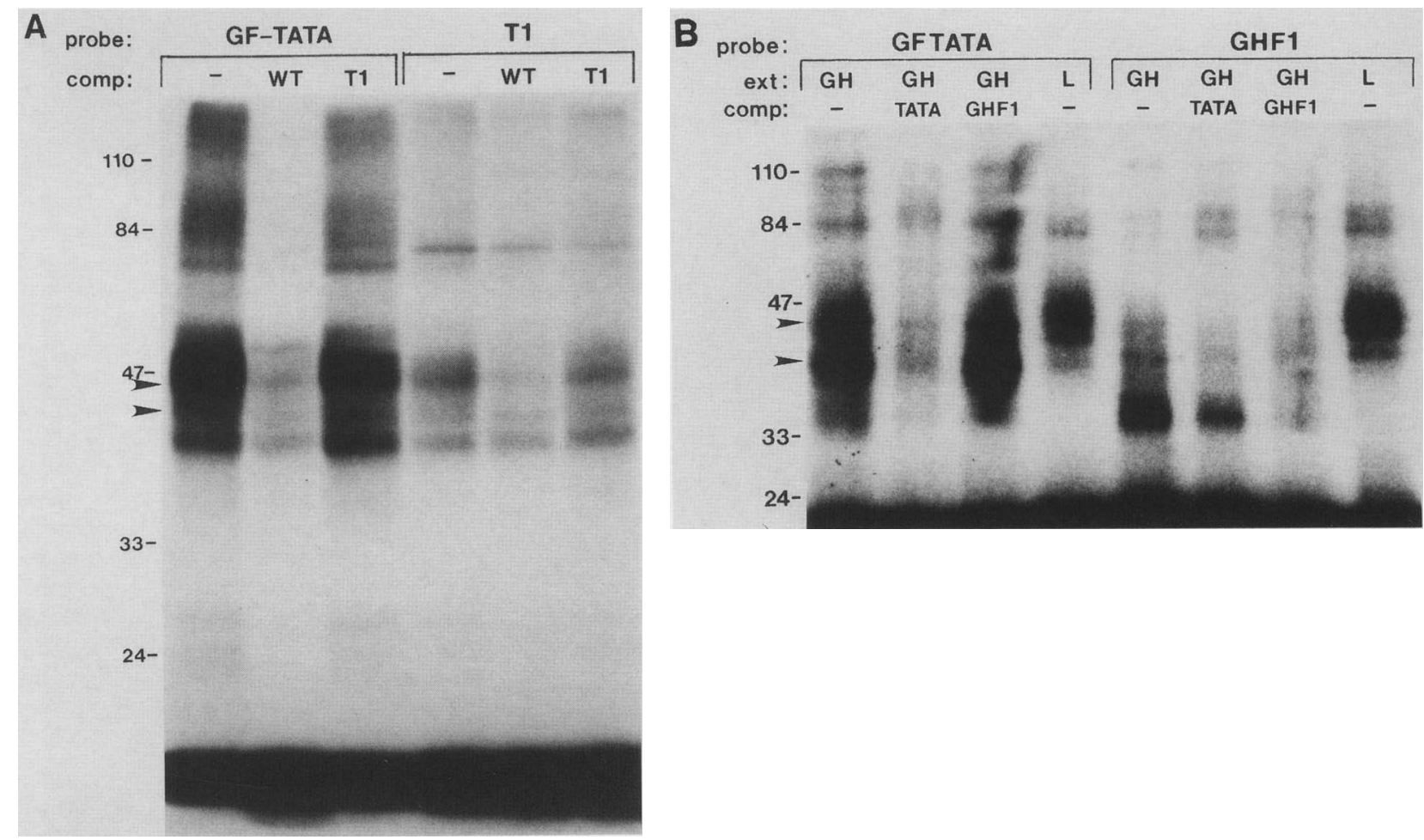

Figure 8. UV-cross-linking analysis of protein binding to the GHF1 TATA element. (A) Labeled wild-type GHF1 TATA element oligonucleotide (GF-TATA) and a labeled oligonucleotide containing the $\mathrm{T} 1 \mathrm{mutation}$ (T1) were incubated with a $0.4 \mathrm{M}$ heparin-agarose fraction of a GH3 WCE in the absence or presence of unlabeled GFTATA (WT) and Tl competitors, prior to UV cross-linking for 15 min. $(B)$ Labeled GF-TATA and GHF1 oligonucleotides were incubated with either GH3 (GH) or $\mathrm{Ltk}^{-}$(L) WCE in the absence or presence of GFTATA and GHF1 competitors prior to UV cross-linking for $5 \mathrm{~min} .(C)$ Labeled GHF1 (GF) and $\alpha$-globin (GL) TATA element oligonucleotides (for sequence, see Fig. 5A) were incubated with GH3 extract in the absence and presence of the various competitors as indicated prior to UV cross-linking for $5 \mathrm{~min}$. ProteinDNA complexes were analyzed by electrophoresis on SDS-polyacrylamide gels and visualized by autoradiography for $36 \mathrm{hr}$. The migration positions of molecular weight standards are indicated; the 40- and 45-kD protein-DNA complexes are marked by arrowheads.

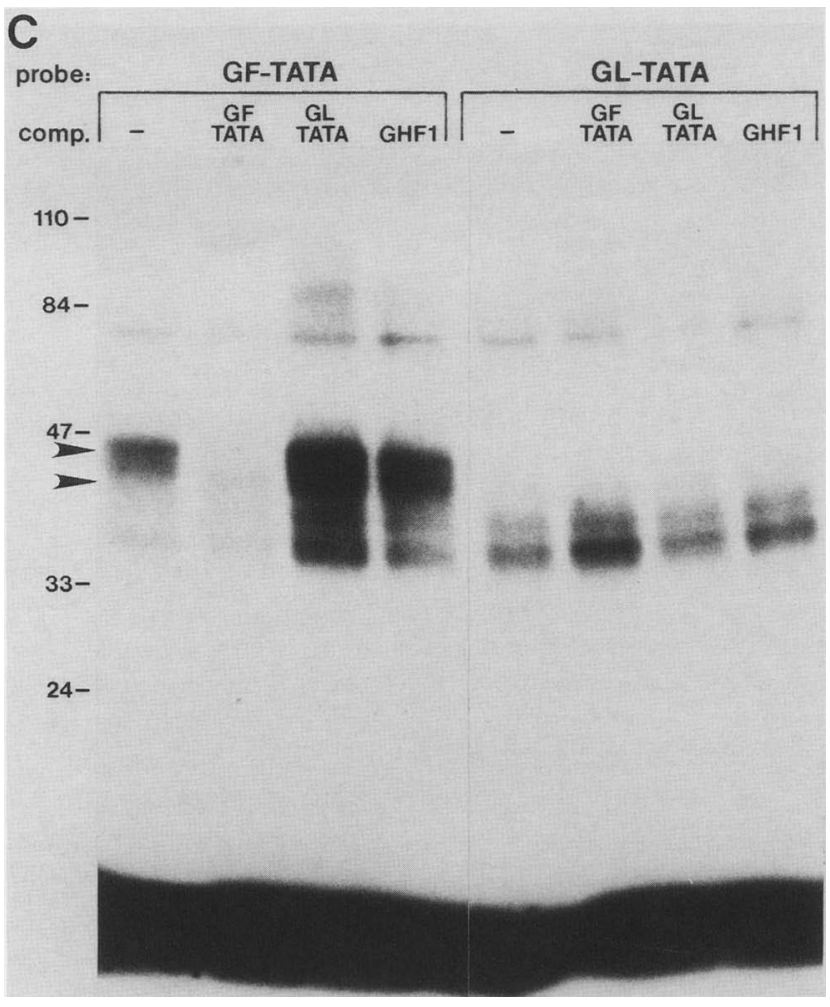

consensus. Substitution of $\mathrm{G}$ for the first $\mathrm{T}$ within this box leads to a marked decrease in transcriptional efficiency. Second, placing the 15-bp GHF1 TATA element upstream of the TATA box of the HSV-TK gene does not augment transcription from the $T K$ start site. Instead, transcription is initiated from a site located $30 \mathrm{bp}$ down- stream of the GHF1 TATA. The proper selection of the initiation site does not depend on sequences outside of the 15-bp GHF1 TATA element because it is functional when inserted either within plasmid sequences (Fig. 4) or within the $T K$ promoter (Fig. 5).

Unlike conventional TATA elements, the GHF1 
Figure 9. Gel filtration analysis of PTF. A heparin-agarose fraction of a GC extract that contained PTF-binding activity was chromatographed on a Sepharose S-300 column. Column fractions were examined for PTF-binding activity with either the UV cross-linking assay $15 \mathrm{~min}$ cross-linking time) with the WT (W) and T1 (T) GHF1 TATA probes $(A)$ or a DNase I footprinting assay with an endlabeled probe derived from the $\Delta 5^{\prime}$ 41GHF1-CAT construct $(B)$. The elution volumes of molecular weight markers are indicated in $A$. The region of protection between positions -23 and -38 of the GHF1 promoter, centered around the TATA box, is indicated at right. The solid line denotes GHF1 sequences; the broken line denotes plasmid sequences. The same fractions were also examined for their ability to stimulate transcription of the GFTATA/TK hybrid promoter $(C)$. Twelve microliters of each fraction was added to $100 \mu \mathrm{g}$ of an Ltk WCE, and the reactions contained $200 \mathrm{ng}$ of each template.

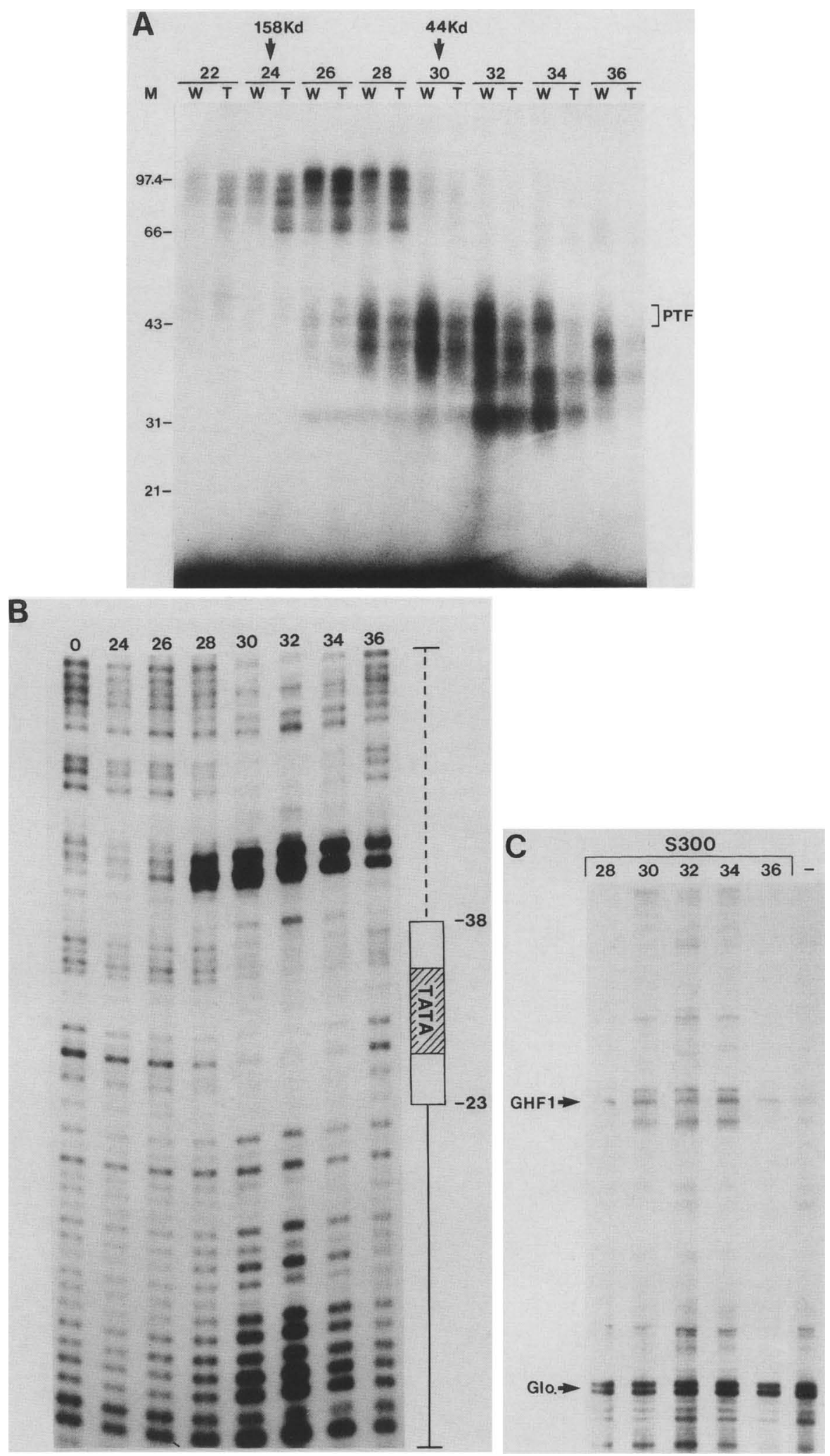

B
TATA element exhibits pronounced cell-type-specificity. Mutagenesis experiments indicate that the TATA element is the major contributor to the cell-type-specific transcription of GHF1 (Figs. 5 and 6; Table 1). Evidence that sequences at the vicinity of the TATA box and the start site of transcription are involved in species-specific transcription was presented previously for the Bombyx mori fibroin gene, whose core promoter is located be- 


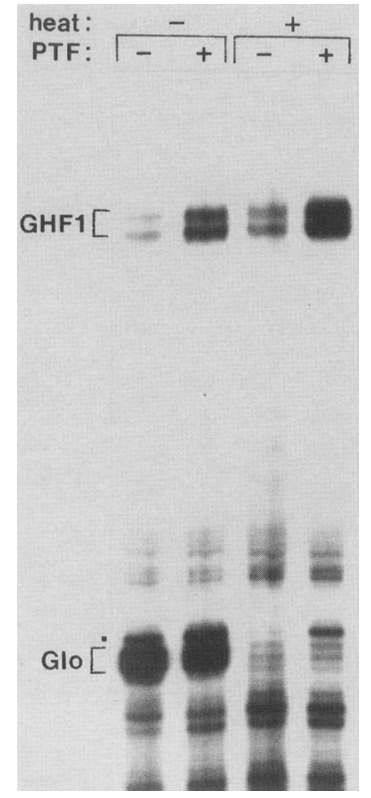

Figure 10. Stimulation of GHF1 transcription by PTF. CMSepharose-concentrated PTF was added as indicated $(7 \mu \mathrm{l} / 20 \mu \mathrm{l}$ reaction) to nuclear extract of GC that was either untreated or preincubated at $47^{\circ} \mathrm{C}$ for $15 \mathrm{~min}$. Control reactions were supplemented with an equal volume of buffer. All reactions included $100 \mathrm{ng}$ of $\Delta 5^{\prime}-41 G H F 1-\mathrm{CAT}$ and $200 \mathrm{ng}$ of the $\alpha$-globin templates. The location of primer extension products corresponding to properly initiated transcripts from the GHF1 and $\alpha$-globin promoters is indicated. The dot indicates the location of prematurely terminated primer extension product of the GHF1-CAT transcripts.

tween positions -37 and +10 (Takiya et al. 1990). In addition, transient transfection experiments suggest that the minimal promoters of the chicken ovalbumin and conalbumin genes are located between positions -56 to -1 and -44 to +62 , respectively (Dierich et al. 1987). However, only in the case of the GHF1 promoter was such an activity localized to a short 15-bp fragment centered around the TATA box itself.

\section{A pituitary-specific transcription factor controlling GHF1}

The differential activity of the GHF1 TATA element implies that it must interact with a transcription factor that is either more abundant or more active in $\mathrm{GH} 3$ cells than in $\mathrm{Ltk}^{-}$cells. A candidate protein responsible for this differential promoter activity was identified by UV cross-linking experiments. This protein, PTF, is more abundant in extracts of GH- and GHF-1-expressing cells and it interacts with the GHF1 TATA element but not with the $\alpha$-globin TATA element. This preference in binding is also reflected in the transcriptional activity of PTF: It stimulates transcription from the GHF1 but not the $\alpha$-globin promoter. Stimulation of GHF1 promoter activity by PTF is observed either after addition to Ltk ${ }^{-}$ extracts, in which it is either absent or present in very low concentration, or after addition to nuclear extracts of GC cells. The discrimination by PTF between the GHF1 and $\alpha$-globin promoters is consistent with the results of the competition experiments which show that the GHF1 TATA element inhibits transcription from the GHF1 but not the $\alpha$-globin promoter. On the basis of these findings, PTF is not likely to be a general transcription factor that affects transcription in a nondiscriminate manner.

Several experiments indicate that the target for PTF is the GHF1 TATA element. The presence of the TATA box within this element raises questions regarding the relationship between PTF and TFIID. Although the relative insensitivity of the GHF1 promoter to incubation of the pituitary cell extracts at $47^{\circ} \mathrm{C}$, a treatment known to inactivate TFIID (Nakajima et al. 1988), may suggest that its transcription in these cells is TFIID independent, further and thorough fractionation of the basic transcriptional machinery is required to determine this point. It is possible that PTF allows heat-inactivated TFIID to interact with the GHF1 and not the $\alpha$-globin promoter by stabilizing its interaction with the GHF1 TATA element. Although it is possible that PTF is identical to TFIID and therefore provides the same function, several experimental results argue against this. First, PTF is much more abundant in GH3 than in $\mathrm{Ltk}^{-}$cells, whereas the level of TFIID antigenic activity (determined by immunoblotting with anti-TFIID antibodies obtained from Dr. A. Berk) is identical in both cell types. Second, these antibodies do not react with partially purified PTF (H. Brady and J. Fukushima, unpubl.). Third, PTF elutes from the gel filtration column as a $40-\mathrm{kD}$ protein while TFIID fractionates on such columns as a $120-\mathrm{kD}$ complex (Reinberg et al. 1987). However, it is still possible that PTF is a modified form of TFIID that behaves differently on gel filtration columns and has lost the ability to interact with anti-TFIID antibodies raised against an amino-terminal peptide of human TFIID. Only after its primary structure is determined can the relationship between PTF and TFIID be fully assessed.

Because TFIID is currently thought to be required for transcription of all TATA box-containing promoters and possibly even for transcription of "TATA-less" RNA polymerase II promoters (for review, see Lewin 1990), we favor the view that PTF acts in conjunction with TFIID on the GHF1 TATA element to confer upon it cell type specificity.

\section{Implications for cell-type-specific gene expression}

Although the GHF1 TATA element is distinct in its celltype-specific activity, it is not the first example of a functionally distinct TATA element. Simon and co-workers (Simon et al. 1988; 1990) have shown that certain TATA elements differ from others in their ability to respond to the viral trans-activator E1A. Although E1A responsiveness appears to be associated with the presence of a specific sequence (TATAA), it is not known whether ElAresponsive TATA elements are recognized by a protein distinct from the one recognizing nonresponsive TATA 
elements. Functionally distinct TATA elements were also described in the late genes of HSV-1 (Homa et al. 1988). It remains to be determined, however, whether these elements are recognized by proteins distinct from those recognizing the TATA elements of immediateearly and early HSV genes. It is likely that these apparently unique classes of TATA elements are all recognized by the general factor TFIID, which was recently shown to be a target for viral trans-activators (Abmayr et al. 1988; Leong et al. 1988; Wu and Berk 1988).

The finding of a cell-type-specific TATA element within the GHF1 promoter and not in other genes is quite intriguing. For example, no such elements were detected in either the $G H$ or prolactin promoters, both of which exhibit similar cell-type specificity (Bodner and Karin 1987; Guttierez-Hartman et al. 1987; McCormick et al. 1988; Nelson et al. 1988). It seems reasonable that primary control of cell-type-specific regulatory genes will be exerted at the most basic level-that of the TATA element. Such a mechanism may ensure that expression of these genes is tightly controlled to prevent low levels of expression in inappropriate cell types. In the case of GHF1, a low level of leaky expression may present a considerable risk, because once activated it is positively autoregulated (McCormick et al. 1990). It remains to be seen, however, whether this regulatory mechanism is generally applied for controlling the expression of celltype-specific trans-activators. It would also be of interest to determine whether negative regulation of PTF activity or expression is responsible for extinction of GHF1 expression in somatic cell hybrids.

\section{Materials and Methods}

\section{In vitro transcription}

Cells used for extract preparation were grown on 150-mm plates as described (McCormick et al. 1988). WCEs were prepared from 3 to $5 \mathrm{ml}$ of packed cells (Bodner and Karin 1987; McCormick et al. 1988). Unless specified otherwise, in vitro transcription reactions contained 75-150 $\mu \mathrm{g}$ of extract protein, $200 \mathrm{ng}$ of the control $\alpha$-globin template, and $100 \mathrm{ng}$ of the specific test template added as supercoiled plasmids. In a standard reaction, WCE in $20 \mu \mathrm{l}$ of buffer (Bodner and Karin 1987) was mixed with the templates in $5 \mu \mathrm{l}$ of $\mathrm{H}_{2} \mathrm{O}$ and incubated for $15 \mathrm{~min}$ on ice before the addition of $20 \mu \mathrm{l}$ of NTP mixture ( $1 \mathrm{~mm}$ each) and 5 $\mu \mathrm{l}$ of $5 \%$ polyvinyl alcohol. RNA synthesis was carried out at $30^{\circ} \mathrm{C}$ for $60 \mathrm{~min}$. Reactions were terminated, and RNA was extracted and analyzed by primer extension as described previously (Bodner and Karin 1987).

\section{Plasmids}

The human $\alpha$-globin gene in pBR322 (Liebhaber et al. 1980) was used as an internal control. GHF1-CAT was described previously (McCormick et al. 1990). The $-200,-90,-50$ and -41 deletion mutants were generated by PCR amplification (Mullis and Faloona 1987) with primers complementary to the various deletion end points and a second primer complementary to GHF1 sequences from -18 to +2 . The amplified products were cloned in front of the CAT structural sequence in the vector pUCAT - (M. Karin, unpubl.), and their sequence was confirmed by dideoxy sequencing (Hattori and Sakaki 1986). The
GHF1/TK constructs were generated by subcloning HindIII-SalI fragments containing GHF1 promoter sequences derived from the appropriate $5^{\prime}$-deletion mutants, in front of HSV-TK $\Delta 5^{\prime}-46$ (McKnight et al. 1981). The GFTATA/TK construct was generated by subcloning of the GHF1 TATA oligonucleotide (see below) upstream of the truncated HSV-TK $\Delta 5^{\prime}-46$ promoter. The HindIII-SalI restriction fragment containing the -200 GHF1 promoter was subcloned into $\mathrm{M} 13 \mathrm{mpl} 19$ and single-stranded DNA was used as a template for site-directed mutagenesis (McCormick et al. 1990|. The mutagenic oligonucleotides 5'-AGGAGGGTCG AGGCTCACCT TAATATGCGA AGGAAATCCA TTTATA-3' and 5'-AGGAGGGTCG AGGCTAGGGT TTATGCTTGG GGGAAATCCA TTTATA-3' were used to convert the GHF1 TATA element to those of the HSV-TK and $\alpha$-globin genes, respectively (see Fig. 5A). The T1-T5 mutants were generated using the same single-stranded template and appropriate mutagenic oligonucleotides spanning the GHF1 TATA. The TK TATA element was converted to that of GHF1 by mutagenizing a BamHI-KpnI fragment containing $T K$ sequences from -109 to +635 subcloned into M13mp19 with the primer 5'-CGAGGCCACA CGCGTAGTAT TTATACTCTG AGTGGACCCT CGGACCGC - 3 '. The sequences of all mutants were directly confirmed by dideoxy sequencing.

\section{UV cross-linking}

The following oligonucleotides were used as competitors and probes for UV cross-linking experiments:

\author{
GHF1-TATA: 5'-AGCTTCAGAGTATAAATACG \\ AGTCTCATATTTATGCAGCT-5' \\ $\alpha$-globin TATA: 5'-AGCTTCCCAAGCATAAACCCG \\ AGGGTTCGTATTTGGGCAGCT-5' \\ GHF-1-binding site: 5'-GATCCCATGCATAAATGTACACAG \\ GGTACGTATTTACATGTGTCTTAA-5'
}

The $20-\mu l$ reaction contained $10 \mu \mathrm{g}$ of protein extract (either WCE or $0.4 \mathrm{M}$ heparin-agarose fraction), $0.3 \mathrm{ng}$ of end-labeled oligonucleotide probe, $1 \mu \mathrm{g}$ of poly[d(I-C)], $10 \mathrm{~mm}$ HEPES $[\mathrm{pH}$ 7.6), $50 \mathrm{~mm} \mathrm{KCl}, 0.1 \mathrm{~mm}$ EDTA, $5 \mathrm{~mm} \mathrm{MgCl}_{2}, 1 \mathrm{~mm} \mathrm{DDT}$, and $10 \%$ glycerol and was incubated for $20 \mathrm{~min}$ on ice. For competition experiments, $25 \mathrm{ng}$ of competitor oligonucleotides was used. UV cross-linking was performed with a Stratagene Stratalinker 254-nm bulb for 5-15 min at a distance of $12 \mathrm{~cm}$. SDS gel sample buffer $(20 \mu 1)$ was added, and samples were heated at $100^{\circ} \mathrm{C}$ for $3 \mathrm{~min}$ and analyzed on $10 \%$ polyacrylamide gels containing SDS.

\section{Partial purification of PTF}

WCE from $20 \mathrm{~g}$ of GC cells was fractionated by $\left(\mathrm{NH}_{4}\right)_{2} \mathrm{SO}_{4}$ precipitation. The $10-65 \%$ saturated $\left(\mathrm{NH}_{4}\right)_{2} \mathrm{SO}_{4}$ fraction was dissolved in $10 \mathrm{ml}$ of buffer A (20 mM HEPES-KOH (pH 7.6), 100 $\mathrm{mM} \mathrm{KCl}, 12.5 \mathrm{~mm} \mathrm{MgCl}_{2}, 0.1 \mathrm{~mm}$ EDTA, $1 \mathrm{~mm} \mathrm{DTT}, 10 \%$ glycerol) containing $0.1 \mathrm{mM}$ PMSF and dialyzed against 1 liter of buffer A containing $0.1 \mathrm{mM}$ PMSF at $4^{\circ} \mathrm{C}$. After clearing (15 min at $10,000 \mathrm{rpm})$, the supernatant was applied to a $25-\mathrm{ml}$ heparinagarose column equilibrated with buffer $\mathrm{A}$ that was eluted by a stepwise $\mathrm{KCl}$ gradient $(0.1-1.0 \mathrm{M})$ in buffer A. PTF activity eluted at $0.4 \mathrm{M} \mathrm{KCl}$ and these fractions were pooled and applied to a 900-ml Sephadex S-300 gel filtration column eluted with buffer A. PTF-containing fractions were pooled and applied to 4 $\mathrm{ml} \mathrm{CM}-$ Sepharose CL-6B column eluted with a linear $0.1-1.0 \mathrm{M}$ $\mathrm{KCl}$ gradient in buffer $\mathrm{A}$.

\section{Acknowledgments}

This work was supported by National Institutes of Health grant 
R01 DK38527-04. H.B. was supported by a U.S. Public Health Service postdoctoral fellowship, and J.F. by a postdoctoral fellowship from the Ministry of Education of Japan. We thank Dr. Peter Geiduscheck for discussions, Dr. Arnold Berk for the antiTFIID antibodies, Dr. Kay Klausing for the computer search, Ed Satuloff for help with cell culture, and Anne Casey for preparation of this manuscript.

The publication costs of this article were defrayed in part by payment of page charges. This article must therefore be hereby marked "advertisement" in accordance with 18 USC section 1734 solely to indicate this fact.

\section{References}

Abmayr, S.M., J.L. Workman, and R.G. Roeder. 1988. The pseudorabies immediate early protein stimulates in vitro transcription by facilitating TFIID : promoter interactions. Genes \& Dev. 2: 542-553.

Baumhueter, S., D.B. Mendel, P.B. Conley, C.J. Kuo, C. Turk, M.K. Graves, C.A. Edwards, G. Courtois, and G.R. Crabtree. 1990. HNF-1 shares three sequence motifs with the POU domain proteins and is identical to LF-Bl and APF. Genes \& Dev. 4: 372-379.

Bodner, M. and M. Karin. 1987. A pituitary-specific trans-activating factor can stimulate transcription from the growth hormone promoter in extracts of nonexpressing cells. Cell 50: $267-275$.

Bodner, M., J.-L. Castrillo, L.E. Theill, T. Deerinck, M. Ellisman, and M. Karin. 1988. The pituitary-specific transcription factor GHF-1 is a homeobox-containing protein. Cell 55: 505-518.

Breathnach, R. and P. Chambon. 1981. Organization and expression of eucaryotic split genes coding for proteins. Annu. Rev. Biochem. 50: 349-383.

Buratowski, S., S. Hahn, P.A. Sharp, and L. Guarente. 1988. Function of a yeast TATA element-binding protein in a mammalian transcription system. Nature 334: 37-42.

Buratowski, S., S. Hahn, L. Guarente, and P.A. Sharp. 1989. Five intermediate complexes in transcription initiation by RNA polymerase II. Cell 56: 549-561.

Castrillo, J.-L., M. Bodner, and M. Karin. 1989. Purification of growth hormone specific transcription factor, GHF-1, containing homeobox. Science 243: 814-817.

Cavallini, B., J. Huet, J. Plassat, A. Sentenac, J. Egly, and P. Chambon. 1988. A yeast activity can substitute for the HeLa cell TATA box factor. Nature 334: 77-80.

Davidson, R.L. 1974. Gene expression in somatic cell hybrids. Annu. Rev. Genet. 8: 195-218.

Dierich, A., M.-P. Gaub, J.-P. LePennec, D. Astinotti, and P. Chambon. 1987. Cell-specificity of the chicken ovalbumin and conalbumin promoters. EMBO I. 6: 2305-2312.

Dollé, P., J.-L. Castrillo, L.E. Theill, T. Deerinck, M. Ellisman, and M. Karin. 1990. Expression of GHF-1 protein in developing mouse pituitaries correlates both temporally and spatially with the onset of growth hormone gene activity. Cell 60: 809-820.

Gonzalez, G.A., K.K. Yamamoto, W.H. Fischer, D. Karr, P. Manzel, W. Biggs III, W.W. Vale, and M.R. Montminy. 1989. A cluster of phosphorylation sites on the cyclic AMP-regulated nuclear factor CREB predicted by its sequence. Nature 337: 749-752.

Gutierrez-Hartmann, A., S. Siddiqui, and S. Loukin. 1987. Selective transcription and DNAase I protection of the rat prolactin gene by GH3 pituitary cell-free extracts. Proc. Natl. Acad. Sci. 84: 5211-5215.
Hahn, S., S. Buratowski, P.A. Sharp, and L. Guarente. 1989. Yeast TATA-binding protein TFIID binds to TATA elements with both consensus and nonconsensus DNA sequences. Proc. Natl. Acad. Sci. 86: 5718-5722.

Hattori, M. and Y. Sakaki. 1986. Dideoxy sequencing method using denatured plasmid templates. Anal. Biochem. 152: 232-238.

Hoffmann, A., E. Sinn, T. Yamamoto, J. Wang, A. Roy, M. Horikoshi, and R.G. Roeder. 1990. Highly conserved core domain and unique $\mathrm{N}$ terminus with presumptive regulatory motifs in a human TATA factor (TFIID). Nature 346: 387-390.

Homa, F.L., J.C. Glorioso, and M. Levine. 1988. A specific 15-bp TATA box promoter element is required for expression of a herpes simplex virus type I late gene. Genes \& Dev. 2: 4053.

Ingrahm, H.A., R. Chen, H.J. Mangalam, H.P. Elsholtz, S.E. Flynn, C.R. Lin, D.M. Simmons, L. Swanson, and M.G. Rosenfeld. 1988. A tissue-specific transcription factor containing a homeodomain specifies pituitary phenotype. Cell 55: 519-529.

Junker, S., S. Pedersen, E. Scheiber, and P. Matthias. 1990. Extinction of an immunoglobulin $\mathrm{k}$ promoter in cell hybrids is mediated by the octamer motif and correlates with suppression of Oct-2 expression. Cell 61: 467-474.

Karin, M., J.L. Castrillo, and L.E. Theill. 1990. Growth hormone gene regulation: A paradigm for cell-type-specific gene activation. Trends Genet. 6: 92-96.

Killary, A.M. and R.E.K. Fournier. 1984. A genetic analysis of extinction: Trans-dominant loci regulate expression of liverspecific traits in hepatoma hybrid cells. Cell 38: 523-534.

Leong, K., L. Brunet, and A.J. Berk. 1988. Factors responsible for the higher transcriptional activity of extracts of adenovirusinfected cells fractionate with the TATA box transcription factor. Mol. Cell. Biol. 8: 1765-1774.

Lewin, B. 1990. Commitment and activation at PolII promoters: A tail of protein-protein interactions. Cell 61: 1161-1164.

Liebhaber, S., M. Goossens, and Y.W. Kan. 1980. Cloning and complete nucleotide sequence of human $55^{\prime}-\alpha$-globin gene. Proc. Natl. Acad. Sci. 77: 7054-7058.

Maniatis, T., S. Goodbourn, and J.A. Fischer. 1987. Regulation of inducible and tissue-specific gene expression. Science 236: $1237-1245$.

McCormick, A., D. Wu, J.-L. Castrillo, S. Dana, J. Strobl, E.B. Thompson, and M. Karin. 1988. Extinction of growth hormone expression in somatic cell hybrids involves repression of the specific trans-activator GHF-1. Cell 55: 379-389.

McCormick, A., H. Brady, L.E. Theill, and M. Karin. 1990. Regulation of the pituitary-specific homeobox gene GHF1 by cell-autonomous and environmental cues. Nature 345: 829832.

McKnight, S.L., E.R. Gavis, R. Kingsbury, and R. Axel. 1981. Analysis of transcriptional regulatory signals of the HSV thymidine kinase gene: Identification of an upstream control region. Cell 25: 385-398.

Mullis, K.S. and F.A. Faloona. 1987. Specific synthesis of DNA in vitro via a polymerase-catalyzed chain reaction. Methods Enzymol. 155: 335-350.

Nakajima, N., M. Horikoshi, and R.G. Roeder. 1988. Factors involved in specific transcription by mammalian RNA polymerase II: Purification, genetic specificity and TATA boxpromoter interactions of TFIID. Mol. Cell. Biol. 8: 40284040 .

Nakatani, Y., M. Brenner, and E. Freese. 1990. An RNA polymerase II promoter containing sequences upstream and downstream from the RNA startpoint that direct initiation of transcription from the same site. Proc. Natl. Acad. Sci. 
87: 4280-4293.

Nelson, C., V.R. Albert, H.P. Elsholtz, L.E.-W. Lu, and M.G. Rosenfeld. 1988. Activation of cell-specific expression of rat growth hormone and prolactin genes by a common transcription factor. Science 239: 1400-1405.

Reinberg, D., M. Horikoshi, and R.G. Roeder. 1987. Factors involved in specific transcription in mammalian RNA polymerase II: Functional analysis of initiation factors IIA and IID and identification of a new factor operating at sequences downstream of the initiation site. J. Biol. Chem. 262: 33223330 .

Renkawitz, R. 1989. Tissue specific gene expression. VCH Publishers, Weinheim.

Schmidt, N.C., C.C. Kao, R. Pei, and A.J. Berk. 1989. Yeast TATA-box transcription factor gene. Proc. Natl. Acad. Sci. 86: 7785-7789.

Serfling, E., M. Jasin, and W. Schaffner. 1985. Enhancers and eukaryotic gene transcription. Trends Genet. 1: 224-230.

Simon, M.C., T.M. Fisch, B.J. Benecke, J.R. Nevins, and N. Heintz. 1988. Definition of multiple, functionally distinct TATA elements, one of which is a target in the hsp70promoter for E1A regulation. Cell 52: 723-729.

Simon M.C., R.J. Rooney, T.M. Fisch, N. Heintz, and J.R. Nevins. 1990. ElA-dependent trans-activation of the c-fos promoter requires the TATAA sequence. Proc. Natl. Acad. Sci. 87: 513-517.

Smale, S.T. and D. Baltimore. 1989. The "initiator" as a transcription control element. Cell 57: 103-113.

Struhl, K. 1989. Molecular mechanisms of transcriptional regulation in yeast. Ann. Rev. Biochem. 58: 1051-1077.

Takiya, S., C. Hui, and Y. Suzuki. 1990. A contribution of the core-promoter and its surrounding regions to the preferential transcription of the fibroin gene in posterior silk gland extracts. EMBO I. 9: 489-496.

Thompson, B. and T.D. Gelehrter. 1971. Expression of tyrosine aminotransferase activity in somatic cell heterokaryons. Evidence for negative control of enzyme expression. Proc. Natl. Acad. Sci. 68: 2589-2593.

Weiss, M.C. and M. Chaplain. 1971. Expression of differentiated functions in hepatoma cell hybrids; reappearance of tyrosine amino-transferase inducibility after the loss of chromosomes. Proc. Natl. Acad. Sci. 68: 3026-3030.

Wu, L. and A.J. Berk. 1988. Transcriptional activation by the pseudorabies virus immediate early protein requires the TATA box element in the adenovirus 2E1B promoter. Virology 167: 318-322. 


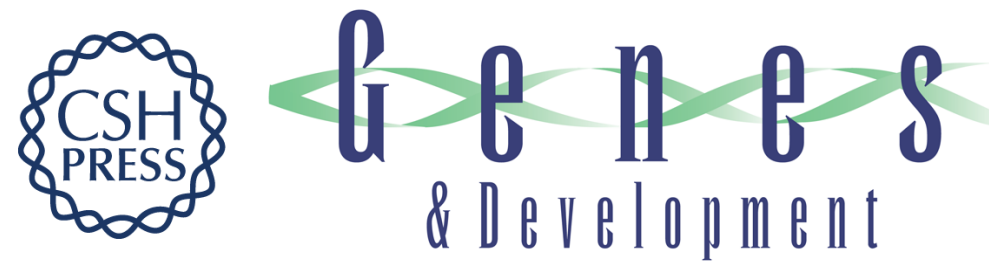

\section{The pituitary-specific regulatory gene GHF1 contains a minimal cell type-specific promoter centered around its TATA box.}

A McCormick, H Brady, J Fukushima, et al.

Genes Dev. 1991, 5:

Access the most recent version at doi:10.1101/gad.5.8.1490

References This article cites 44 articles, 17 of which can be accessed free at: http://genesdev.cshlp.org/content/5/8/1490.full.html\#ref-list-1

License

Email Alerting

Service

Receive free email alerts when new articles cite this article - sign up in the box at the top right corner of the article or click here.

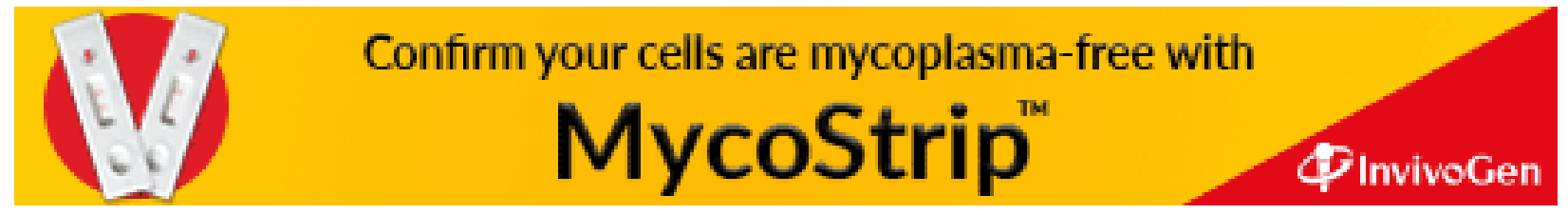

